\title{
DETERMINATION OF LANDSLIDE SLIP PLANE USING GEOLOGY AND GEOELECTRICAL ANAL YSIS AT MOUNT GEGER PULUS LEGOK EMO SLOPE SEGMENT, CILILIN, WEST JAVA
}

\section{PENENTUAN BIDANG GELINCIR LONGSOR DENGAN ANALISIS GEOLOGI DAN GEOLISTRIK DI GUNUNG GEGER PULUS SEGMEN LERENG LEGOK EMO, CILILIN, JAWA BARAT}

\author{
Iwan G. Tejakusuma ${ }^{1}$, Puspa Khaerani ${ }^{1}$, Syakira Trisnafiah ${ }^{1}$, Achmad F. Shomim ${ }^{1}$, \\ Wisyanto $^{1}$, dan Heru S. Naryanto ${ }^{1}$ \\ ${ }^{1}$ Pusat Teknologi Reduksi Risiko Bencana - TPSA - BPPT \\ Gedung BPPT Lantai 12, Jl. M. H. Thamrin No. 8, Jakarta Pusat 10340 \\ e-mail: iwan.tejakusuma@gmail.com
}

\begin{abstract}
Mount Geger Pulus in Cililin District, West Java exhibit a cone geomorphology composed of an Andesitic intrusion, in which, part of the slope is covered by volcanic rock. Small to moderate landslides have occurred several times in the area of this mount, indicating that the area has the potential for landslides. Detailed research is needed aims to determine the potential of landslides on slope segments with landslides risk. Based on field observations, these conditions are found in the area of Legok Emo slope segment. In this segment, small scale landslides have occurred several times with settlement lies around the bottom of this slope. The sloping segment of Legok Emo has a steep to a very steep, covered by secondary and mixed forests. The results of geoelectrical measurements and geological analysis of this slope segment indicate that the slope has the potential to a landslide that is controlled by tuff acting as a slip plane and can be triggered by rainfall. The layer that has the potential to landslide is weathered volcanic breccias with a thickness of about 3 meters with a maximum of 5 meters that is overlying tuff which is relatively impermeable.
\end{abstract}

Keywords: cone geomorphology, slope, lithology control, slip plane, rainfall trigger.

\begin{abstract}
Abstrak
Gunung Geger Pulus di Kecamatan Cililin, Jawa Barat memiliki geomorfologi menyerupai kerucut yang merupakan intrusi Andesit dimana sebagian lerengnya ditutupi oleh batuan vulkanik. Longsor kecil hingga sedang pernah terjadi beberapa kali di daerah gunung ini, menunjukkan bahwa lokasi ini memiliki potensi longsor. Penelitian lebih detail diperlukan dengan tujuan untuk mengetahui potensi longsor pada segmen lereng yang mempunyai risiko bencana longsor. Berdasarkan pengamatan lapangan, kondisi tersebut terdapat pada daerah segmen lereng Legok Emo. Segmen lereng ini pernah mengalami longsor kecil dengan permukiman terdapat di bagian bawah lereng. Pada segmen lereng ini, kemiringan lereng dijumpai curam hingga sangat curam ditutupi oleh hutan sekunder dan kebun campuran. Hasil pengukuran dan analisis geolistrik dan geologi pada segmen ini menunjukkan bahwa bagian lereng ini memiliki potensi longsor yang dikontrol oleh batuan tuf sebagai bidang gelincir dan longsor dapat dipicu oleh curah hujan. Lapisan yang mungkin longsor merupakan batuan breksi terlapukkan di permukaan dengan ketebalan sekitar 3 meter dan maksimum 5 meter yang berada di atas batuan tuf yang relatif kedap air.
\end{abstract}

Kata Kunci: geomorfologi kerucut, kemiringan lereng, kontrol litologi, bidang gelincir, curah hujan. 


\section{PENDAHULUAN}

Kajian bahaya longsor diperlukan khususnya pada daerah dengan risiko bencana longsor. Ancaman bencana dihadapi oleh penduduk yang tinggal di sekitar lereng yang mempunyai potensi longsor. Demikian pula pada lokasi lereng lainnya pada jalur transportasi atau lokasi strategis lainnya, dimana kejadian longsor dapat mengganggu aktivitas ekonomi dan kehidupan masyarakat. Berbagai metode telah dilakukan untuk mengkaji bahaya longsor baik dengan skala regional yaitu melihat secara kewilayahan maupun secara detail melalui survei lapangan, pengamatan geologi dan pengukuran dengan metode geofisika.

Metode pengkajian bahaya longsor dengan skala regional telah dilakukan misalnya oleh Segoni et al. (2018) di bagian utara Tuscany, Italia, dengan cara memadukan ambang batas curah hujan dengan peta kerentanan untuk penilaian bahaya longsor yang dinamis; Yusof et al. (2015) di sepanjang koridor Jelapang, Jalan Tol Utara - Selatan di Malaysia dengan menggunakan data LiDAR resolusi tinggi dan Kirschbaum et al. (2015) di Amerika Tengah dan Hispaniola yang mengintegrasikan peta kerentanan regional dan perkiraan curah hujan berbasis satelit ke dalam binary decision tree (pohon keputusan biner), dengan mempertimbangkan baik curah hujan harian maupun curah hujan pendahuluan.

Pengkajian bahaya longsor dengan metode skala yang lebih detail telah dilakukan seperti oleh Lidauer et al. (2018) di lokasi longsor Salcher di Gresten, Austria Selatan dengan mengintegrasikan pengukuran geoteknik, hidrologi, meteorology, dan geolistrik dalam satu sistem untuk meneliti dinamika longsor secara detail. Pengukuran geolistrik banyak digunakan dalam penelitian longsor skala rinci. Beberapa peneliti yang menggunakan metode geolistrik dalam mengkaji longsor diantaranya oleh Azman (2018) yang mengkaji gerakan tanah dengan menggunakan geolistrik di Pulau Penang, Malaysia sedangkan Pratiwi et al. (2018) meneliti bidang gelincir gerakan tanah dengan geolistrik pada bentang alam transisi vulkanik Kuarter (Gunung Sumbing) dan Tersier (Gunung Menoreh) di sub daerah aliran sungai Bompon di Jawa Tengah. Selain itu Akmam et al. (2019) meneliti gerakan tanah di Malalak, Kabupaten Agam, Sumatra Barat dengan geolistrik dengan mengimplementasikan metode least square contrain inversion method. Demikian pula Yatini dan Suyanto (2018) yang meneliti bidang gelincir longsor di
Kecamatan Gedangsari, Kabupaten Gunungkidul di Daerah Istimewa Yogyakarta dan Daryono et al. (2018) yang mengidentifikasi longsor dengan analisis geologi dan geolistrik di jalan Pacitan Ponorogo, Jawa Timur.

Gunung Geger Pulus dan daerah sekitarnya, di Kecamatan Cililin, Kabupaten Bandung Barat, Jawa Barat merupakan salah satu daerah yang memiliki risiko bencana longsor. Daerah ini pernah mengalami beberapa kejadian longsor seperti pada 10 Maret 2017 di Kampung Jati Radio, Desa Cililin dan pada 27 Februari 2017 di Kampung Cinangsi, Desa Karangtanjung. Daerah ini telah diteliti sebelumnya secara singkat oleh Badan Geologi, (2017a) dan Badan Geologi (2017b) sedangkan Tejakusuma (2017) juga telah melakukan penelitian lebih detail mengenai lokasi longsor di Kampung Jati Radio, Kecamatan Cililin, Kabupaten Bandung Barat, Jawa Barat.

Lokasi yang pernah mengalami longsor Gunung Geger Pulus yaitu lereng yang mengarah ke Kampung Jati Radio lebih kurang di sebelah utara Puskesmas Cililin. Risiko bencana longsor dihadapi oleh penduduk di sekitar lereng gunung tersebut sehingga perlu dilakukan investigasi kondisi lereng sekitarnya yaitu ke arah utara - barat laut. Daerah ini adalah lokasi Legok Emo dimana di bagian bawah lereng tersebut terdapat perumahan penduduk yang terancam oleh longsor yang mungkin datang dari lereng ini. Lokasi lereng Legok Emo berada sekitar 200 meter sebelah barat lokasi lereng Jati Radio. Lokasi Legok Emo ini menjadi fokus penelitian yang akan diuraikan pada tulisan ini. Tujuan penelitian ini adalah untuk mengetahui potensi longsor yang ada. Dengan mengetahui lebih detail kondisi lereng, maka dapat dilakukan langkah mitigasi bencana longsor yang lebih tepat.

\section{METODE PENELITIAN}

Metode penelitian yang dilakukan mencakup:

- Studi pustaka baik dari laporan, jurnal maupun sumber lain yang didapat dari penelusuran internet.

- Survei lapangan yang mencakup pengamatan dan pengukuran kondisi geologi, litologi, kemiringan lereng, hidrologi, penggunaan lahan, dan informasi dari penduduk lokal setempat.

- Data parameter sifat fisik tanah yang didapatkan dari hasil survei lapangan berupa deskripsi singkapan dan survei pemboran untuk mendapatkan sampel 
tanah tidak terganggu atau undisturbed sample. Tanah tidak terganggu diambil menggunakan core barrels dengan panjang 0,5 meter dan diambil pada kedalaman 3 meter, 6 meter, dan 8 meter. Data penyelidikan tanah yang digunakan dalam analisis ini meliputi analisis laboratorium. Data laboratorium yang dihasilkan berupa index properties untuk mengetahui berat basah, berat kering kadar air, dan berat jenis. Kemudian Atterberg Limit Test untuk mengetahui batas likuid, batas plastis, dan indeks plastisitas. Selain itu dilakukan juga Analisis Distribusi Besar Butir dan Analisis Hidrometer untuk mengetahui besar butir pada sampel yang diambil.

- Metode geolistrik digunakan sebagai salah satu dari metode geofisika yang mempelajari sifat arus listrik di dalam bumi dan bagaimana mendeteksinya di permukaan bumi sehingga didapatkan sebuah penampang pseudosection 2D. Dalam penelitian ini, dilakukan survei geolistrik yang dapat memberikan informasi struktur batuan bawah permukaan dengan konfigurasi Wenner-Alpha (gambar 1). Lintasan pengukuran dibagi ke dalam dua lintasan yaitu lintasan 1 dan lintasan 2 di lereng Legok Emo, yang lebih kurang tegak lurus satu dengan yang lain. Panjang masing-masing lintasan $235 \mathrm{~m}$ dengan jarak terkecil antar elektrode 2,5 m. Lintasan menggunakan sistem bentangan saling memotong (cross) untuk memperoleh gambaran lapisan bawah permukaan batuan baik searah dengan lapisan batuan maupun yang memotong lapisan batuan. Lintasan 1, mengikuti arah kemiringan lereng dan memotong kontur yaitu lintasan berarah Utara $65^{\circ}$ Timur atau barat daya - timur laut, sedangkan Lintasan 2 searah dengan kontur yaitu lintasan berarah Utara $350^{\circ}$ Timur atau barat laut tenggara, (gambar 2). Instrumen yang digunakan adalah geolistrik ARES G5 dengan 48 elektrode aktif yang memiliki kemampuan dalam pembacaan output respon tegangan akibat arus yang diinjeksikan ke bawah permukaan sebagai arus dan potensial. Konfigurasi yang digunakan adalah konfigurasi WennerAlpha dengan empat elektrode dimana jarak antar $\mathrm{C}_{1} \mathrm{P}_{1}=\mathrm{P}_{1} \mathrm{P}_{2}=\mathrm{P}_{2} \mathrm{C}_{2}=\mathrm{a}$, sehingga sistem aturan spasi konstan dengan catatan faktor pengali ' $n$ ' adalah perbandingan jarak antara elektrode C1-P1 atau C2-P2 dengan P1-P2 untuk faktor geometri 2 kali dari spasi (gambar 1).

- GPS Geo Tracker suatu program aplikasi yang diunduh dari Play Store pada smartphone dan handheld GPS Garmin juga digunakan pada pengukuran geolistrik untuk menentukan posisi dan elevasi elektrode sekaligus mengetahui perbandingan ketelitian hasil kedua cara pengukuran tersebut.

- Data yang diperoleh diolah dengan menggunakan software Res2dinv 3.5.3 dengan input data dari instrumen yang memiliki informasi besaran resistivitas semu zona penelitian termasuk konfigurasi spasialnya. Data ini diolah dan dihasilkan sebuah penampang pesudosection 2D sebagai model inversi 2D terhadap data lapangan. Interpretasi struktur batuan bawah permukaan dilakukan berdasarkan nilai tahanan jenisnya.

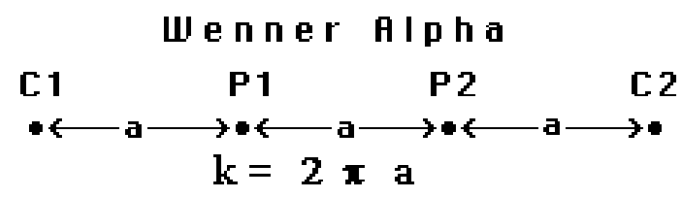

Gambar 1. Konfigurasi Wenner Alpha (modifikasi dari gambar Loke, 1999).

\section{HASIL DAN PEMBAHASAN}

\subsection{Geologi dan Geomorfologi}

Gunung Geger Pulus di Kecamatan Cililin, Kabupaten Bandung Barat, Jawa Barat mempunyai geomorfologi yang khas berbentuk kerucut dengan ketinggian puncaknya sekitar 925 meter di atas permukaan laut. Geomorfologi ini merupakan ciri khas dari batuan intrusi, berupa batuan beku yang mengintrusi batuan yang lebih tua. Menurut Sudjatmiko (1972), batuan intrusi gunung ini merupakan batuan beku Andesit yang mengandung augit, hiperstene dan hornblende dengan matriks yang mengaca. Peta geologi, geomorfologi dan kontur Gunung Geger Pulus dan lokasi pengukuran geolistrik dapat dilihat pada gambar 2. Geomorfologi Gunung Geger Pulus merupakan kerucut intrusi Andesit dengan sebagian lerengnya khususnya bagian tengah dan bawah ditutupi oleh batuan vulkanik. Kemiringan lereng di segmen lereng Legok Emo adalah sedang hingga terjal sehingga rawan longsor.

Tutupan lahan di gunung ini berupa hutan sekunder diselingi dengan kebun campuran berupa kopi dan tanaman buah-buahan. Sebagian lereng ditanami pohon kayu dan bambu yang pada waktu tertentu juga dipotong sebagai bagian dari aktivitas perekonomian warga. 
Pada sisi lereng bagian utara gunung, kemiringan lereng berkisar antara $35^{\circ}$ hingga $22^{\circ}$. Pada bagian lereng Legok Emo (lihat gambar 2), ditemukan alur cekungan kecil merupakan tempat mengalirnya air ketika musim hujan tiba. Aliran ini cukup besar pada musim hujan namun pada musim kemarau menjadi kering. Pada kondisi curah hujan yang tinggi, aliran airnya cukup besar sehingga menyebabkan banjir di lokasi permukiman warga yang tinggal di lereng bagian bawahnya.

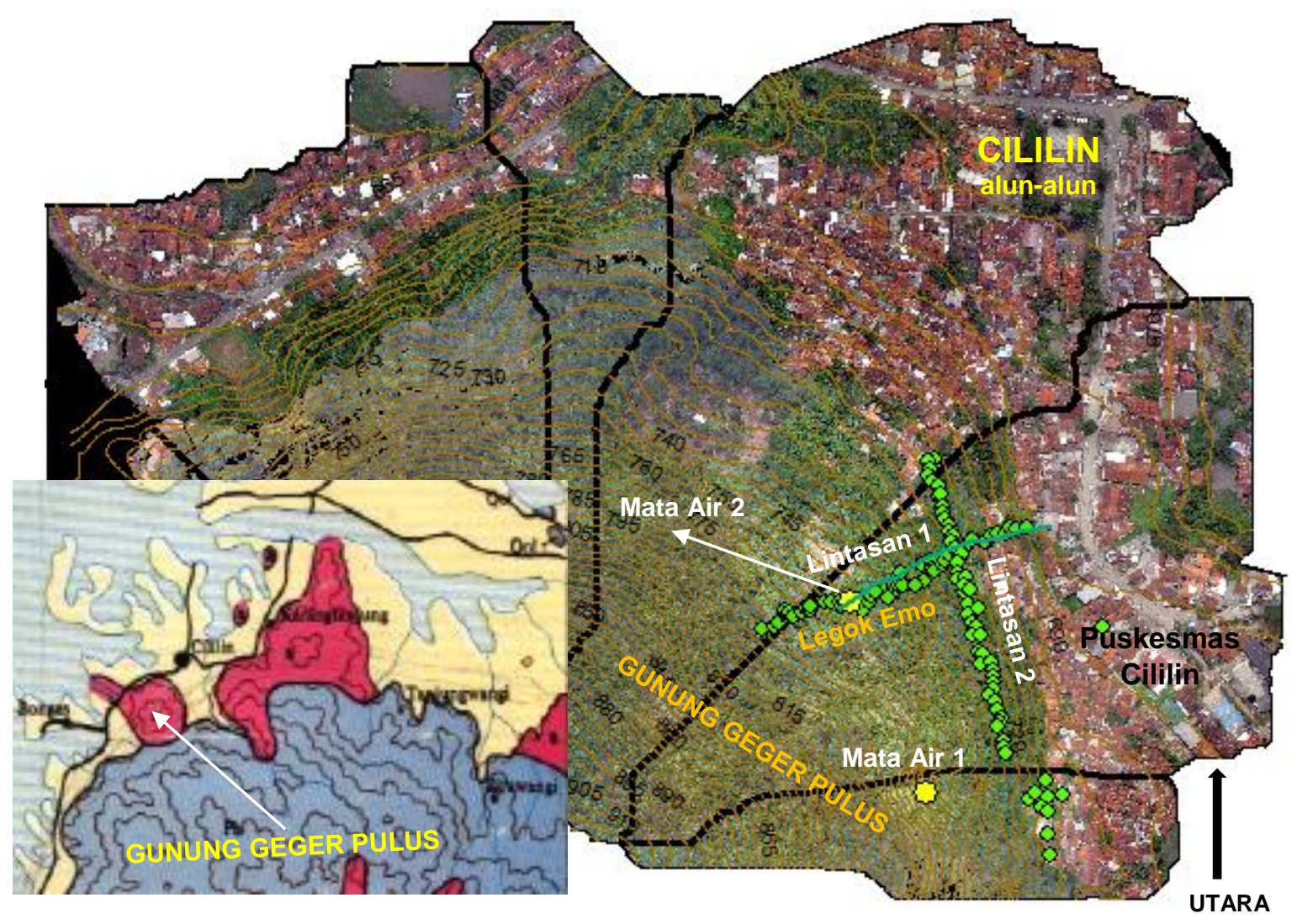

Gambar 2. Geologi daerah Gunung Geger Pulus dan Legok Emo (kiri bawah, peta diambil dari Sudjatmiko, 1972) dan geomorfologi daerah tersebut (kanan) yang memperlihatkan garis kontur ketinggian, lokasi lintasan geolistrik dan mata air.

Longsor yang signifikan dilaporkan belum pernah terjadi di Legok Emo, namun pada waktu curah hujan yang tinggi pada tanggal 27 April 2019, bagian lereng di rumah warga di kaki lereng Legok Emo longsor. Curah hujan yang tinggi merupakan pemicu terjadinya longsor tersebut.

\subsection{Litologi}

Litologi daerah Gunung Geger Pulus merupakan batuan beku Andesit yang singkapannya dapat ditemukan di bagian sekitar ke arah puncak gunung tersebut, di selatan Kampung Jati Radio yang pernah mengalami longsor pada 10 Maret 2017. Di bagian kaki lereng di sekitar jalan setapak dekat Legok Emo dijumpai batuan gunung api berupa breksi dan batupasir tufan yang lebih muda, menutupi batuan Andesit tersebut. Singkapan juga ditemukan pada lereng yang dikupas oleh penduduk untuk keperluan pertanian, perumahan, dan pemakaman serta jalan. Mata air juga ditemukan di lereng Legok Emo (mata air 2 di gambar 2) dan mata air di lokasi longsor Jati Radio (mata air 1 di gambar 2). Mata air ini menunjukkan adanya lapisan akuifer dan lapisan kedap air dimana batas kedua lapisan tersebut terpotong oleh lereng sehingga muncul sebagai mata air.

Pada lokasi 657'17,5' Lintang Selatan (LS) dan $107^{\circ} 27^{\prime} 24,9^{\prime \prime}$ BT (Bujur Timur), dengan ketinggian 736 meter di atas permukaan laut terdapat lereng yang dikupas berarah Utara $210^{\circ}$ Timur untuk pemakaman keluarga (gambar 3). Pada lokasi ini tersingkap lebih kurang lereng dengan panjang 4,7 $\mathrm{m}$ dan tinggi $3,3 \mathrm{~m}$. Singkapan 
tersebut diperkirakan merupakan batuan breksi vulkanik yang terlapukkan dan dari atas ke bawah menunjukkan perubahan tingkat pelapukan yang bergradasi tanpa menunjukkan lapisan yang tegas. Mulai dari lapisan paling atas berupa residual soil, kemudian completely weathered zone di bagian tengah dan highly weathered zone pada bagian bawah (gambar 3). Berdasarkan sistem klasifikasi Unified Soil Classification System atau USCS (ASTM, 1982), tanah yang tersingkap di lokasi tersebut merupakan lempung plastisitas tinggi atau $\mathrm{CH}$ (clay highplasticity). Deskripsi tanah berurutan dari bagian atas, tengah dan bawah dijelaskan sebagai berikut.

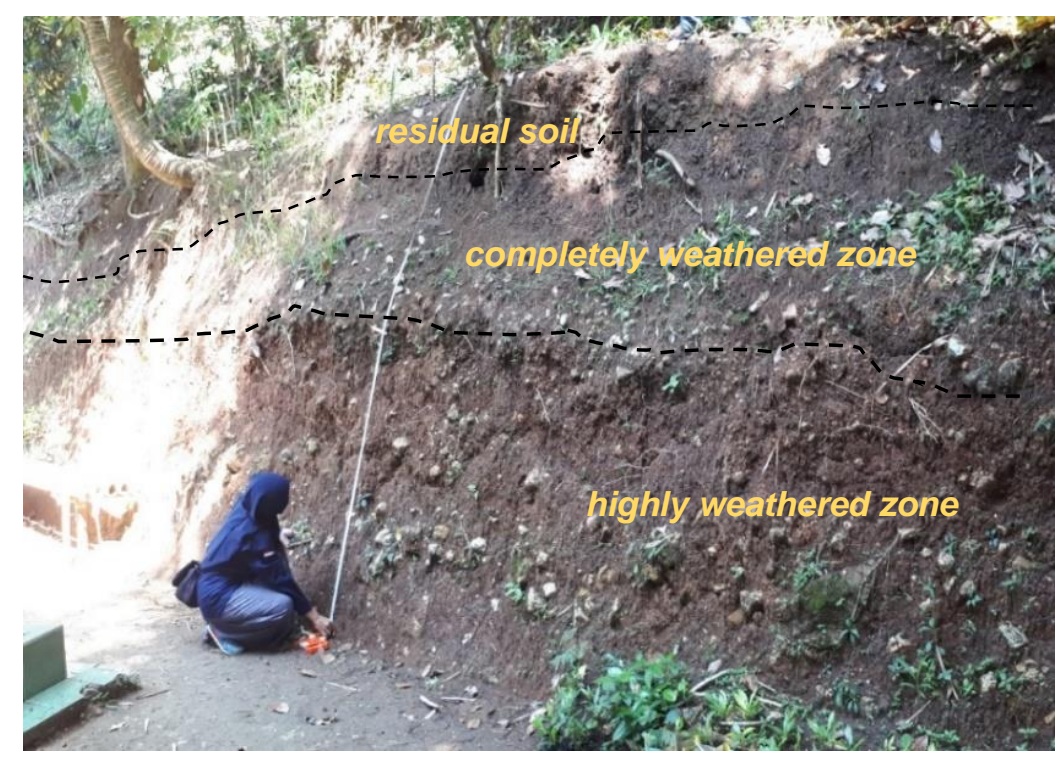

Gambar 3. Tingkat pelapukan pada singkapan tanah di Geger Pulus.

Bagian atas merupakan tanah non kohesif, kondisi sangat lepas, tersementasi buruk, berwarna coklat tua kehitaman, non plastis, mengandung humus atau berserat; bentuk partikel menyudut, equidimensional dengan tekstur kasar; ukuran partikel tanah organik lanau, perlapisan sedang, kondisi kering, terlapukkan sempurna atau berupa residual soil (gambar 4). Bagian tengah merupakan tanah non kohesif, sangat lepas, tersementasi buruk, berwarna coklat kemerahan, non plastis, perlapisan homogen; bentuk partikel menyudut, equidimensional, dengan tekstur kasar; ukuran partikel tanah halus lanau, perlapisan sedang, kondisi kering, tingkat pelapukan completely weathered (gambar 5).

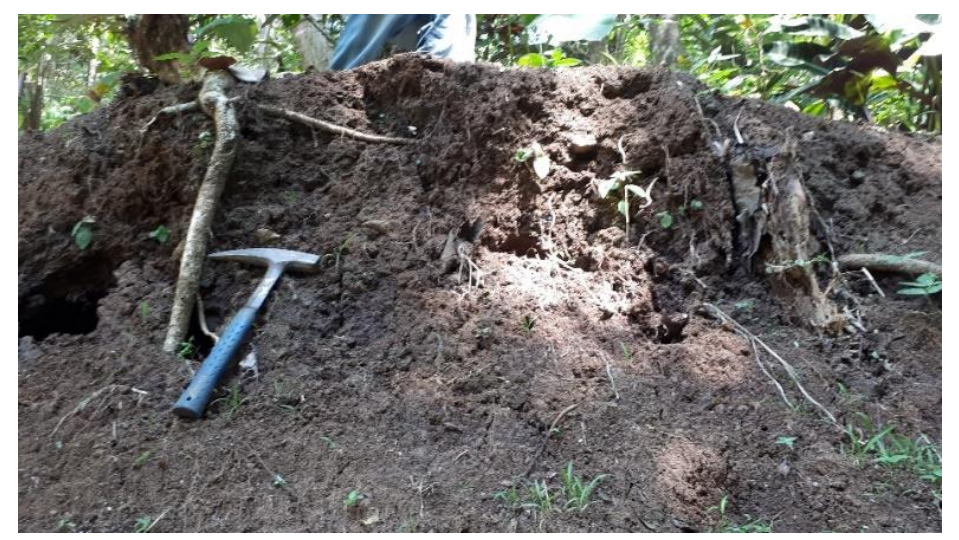

Gambar 4. Lapisan tanah bagian atas, residual soil, mengandung humus. 


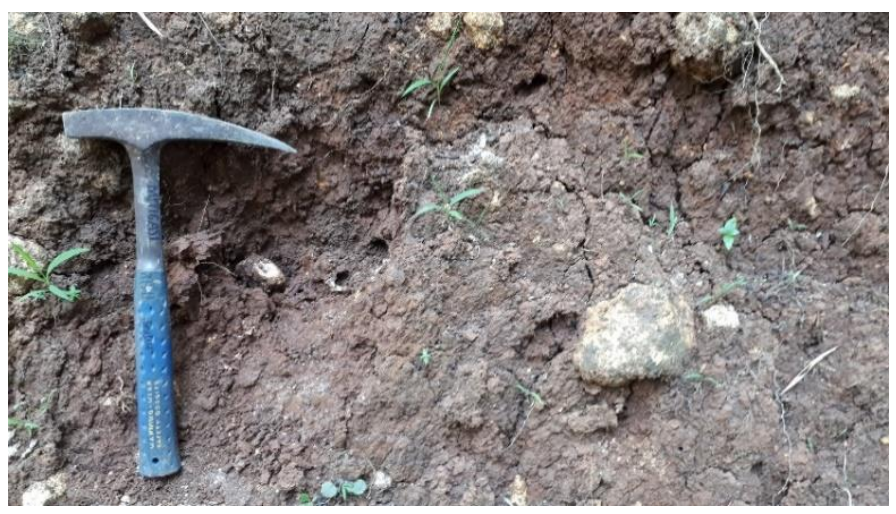

Gambar 5. Lapisan tanah bagian tengah, completely weathered.

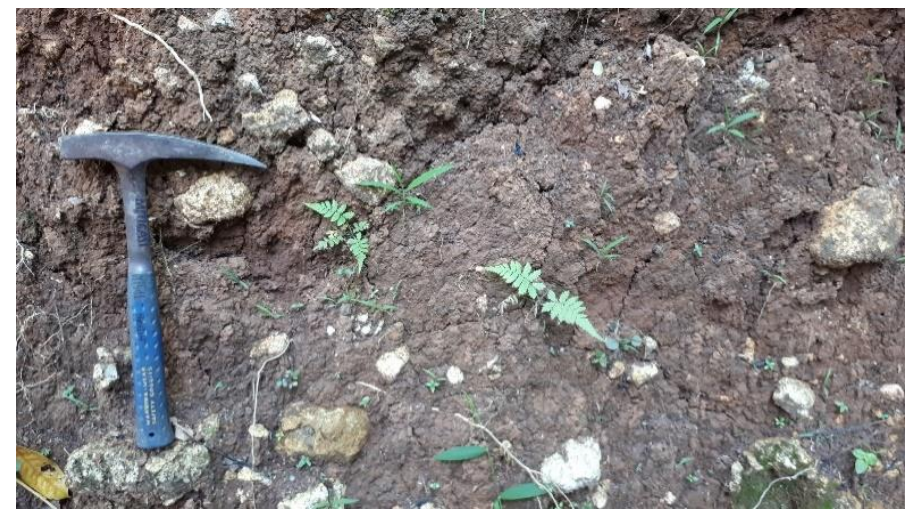

Gambar 6. Lapisan tanah bagian bawah, highly weathered zone.

Bagian bawah berupa tanah kohesif, kondisi lepas tersementasi buruk, berwarna coklat terang kemerahan, agak plastis, struktur perlapisan homogen; bentuk partikel menyudut, equidimensional, tekstur kasar; ukuran partikel berupa tanah halus lanau, perlapisan sedang, kering, dan tingkat pelapukan highly weathered zone (gambar 6).

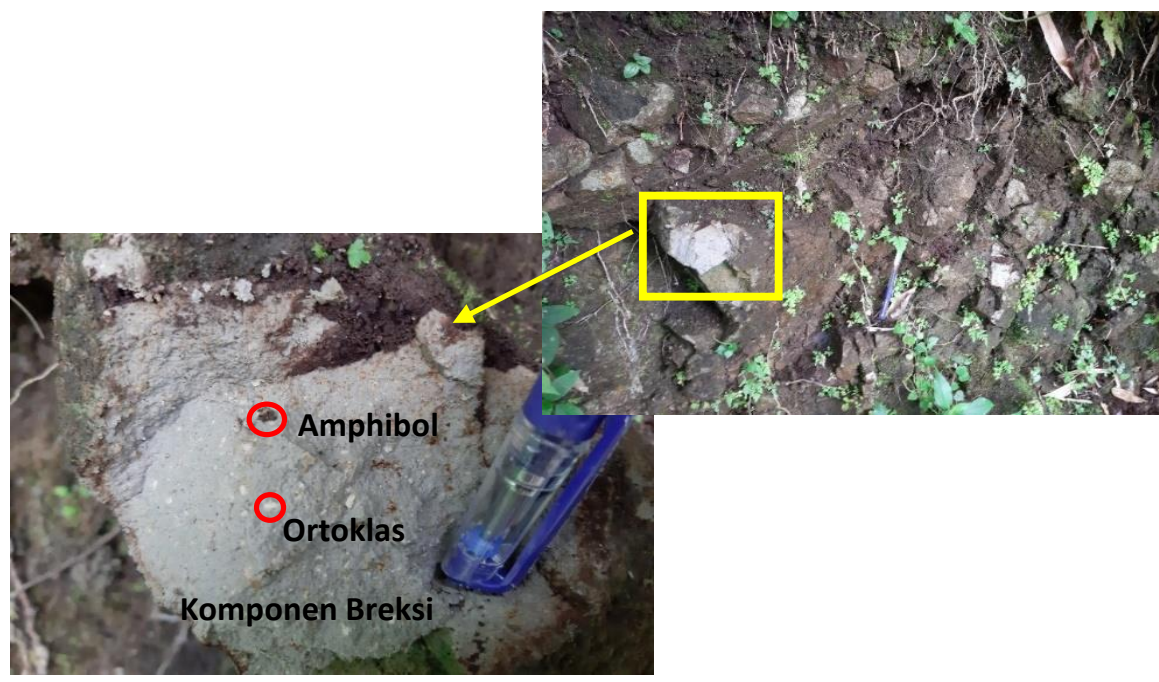

Gambar 7. Singkapan breksi vulkanik moderately weathered, menunjukkan komponen batuan beku dan matriks tuf pasiran. 


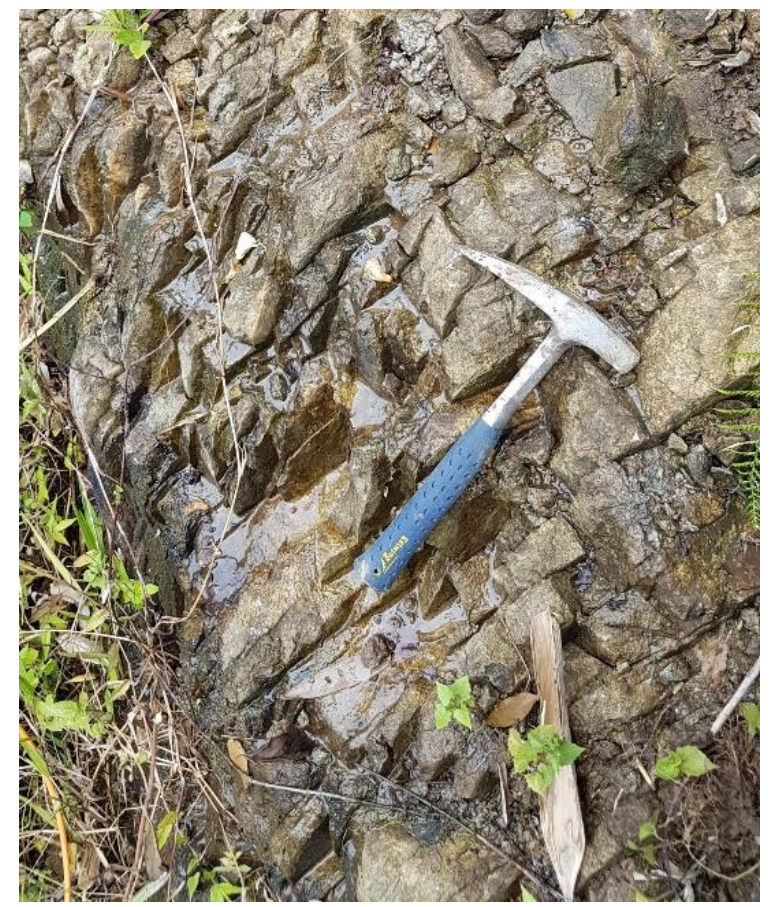

Gambar 8. Batuan beku Andesit tersingkap di Gunung Geger Pulus segmen lereng bagian atas Jati Radio.

Berdasarkan hasil evaluasi sifat fisik tanah di lapangan, analisis laboratorium dan litologi yang didukung dari data hasil analisis bor, maka daerah penelitian dapat diidentifikasi memiliki satu satuan persebaran tanah yaitu Lempung Plastisitas Tinggi atau $\mathrm{CH}$. Satuan ini merupakan hasil pelapukan batupasir tufan yang memiliki kandungan material halus lempung-lanau. Sampel yang diambil merupakan sampel tidak terganggu atau undisturbed sample pada kedalaman $3 \mathrm{~m}-8.5$ $\mathrm{m}$ dan hasil analisis sifat fisik tanah dapat dilihat pada tabel 1.

Tabel 1. Kondisi sifat fisik tanah daerah Gunung Geger Pulus.

\begin{tabular}{r|c|c|c}
\cline { 2 - 4 } & \multicolumn{3}{c}{ Nama TitiK Bor dan Kedalaman } \\
\cline { 2 - 4 } & $\begin{array}{c}\text { BH-01 } \\
\text { Kerikil }\end{array}$ & $\begin{array}{c}\text { BH-01 } \\
\mathbf{6 . 0} \mathbf{- 6 . 5} \mathbf{~ m}\end{array}$ & $\begin{array}{c}\text { BH-01 } \\
\mathbf{8 . 0 - 8 . 5 ~} \mathbf{~ m}\end{array}$ \\
\hline Pasir & $3.04 \%$ & $0 \%$ & $0 \%$ \\
\hline Lanau & $22.24 \%$ & $2.17 \%$ & $0.95 \%$ \\
\hline Lempung & $74.72 \%$ & $73.68 \%$ & $21.20 \%$ \\
\hline Kadar air (Wn) & $54.630 \%$ & $57.240 \%$ & $77.85 \%$ \\
\hline Berat Jenis (Gs) & 2.587 & 2.587 & $61.880 \%$ \\
\hline Berat Basah (gm) & $1.563 \mathrm{~g} / \mathrm{cm}^{3}$ & $1.545 \mathrm{~g} / \mathrm{cm}^{3}$ & $1.519 \mathrm{~g} / \mathrm{cm}^{3}$ \\
\hline Batas Cair (LL) & $86.76 \%$ & $87.75 \%$ & $0.938 \mathrm{~g} / \mathrm{cm}^{3}$ \\
\hline Batas Plastis (PL) & $32.33 \%$ & $32.18 \%$ & $93.98 \%$ \\
\hline Indeks Plastis (IP) & $54.43 \%$ & $55.57 \%$ & $33.04 \%$ \\
\hline
\end{tabular}

Dengan melihat nilai dari Indeks Plastisitas yang didapatkan dari hasil Atterberg Limit Test, diketahui nilai dari tiap sampel undisturbed di kedalaman tertentu menghasilkan nilai yang lebih besar dari $50 \%$. Hal ini mengindikasikan 
tanah hasil lapukan tersebut merupakan tanah dengan jenis plastisitas tinggi.

Dari hasil analisis distribusi besar butir partikel, diketahui dari tiga sampel tanah dengan kedalaman tertentu didominasi oleh lempung lebih dari $70 \%$, lanau dengan persentase lebih dari $20 \%$, dan tanpa kandungan kerikil sama sekali.

\subsection{Hasil Analisis Geolistrik}

Pada penelitian ini digunakan alat geolistrik ARES G5 untuk mengetahui kondisi geologi bawah permukaan. Lokasi elektrode yang dipasang sepanjang bentangan kabel geolistrik diukur posisinya dengan GPS Geo Tracker dan handheld GPS Garmin. Hasilnya menunjukkan bahwa untuk routing atau positioning, ketelitian GPS Geo Tracker melebihi dari handheld GPS Garmin. Hasil pengukuran posisi oleh GPS Garmin apabila di-plot akan menunjukkan posisi elektrode yang berbentuk zig zag atau tidak lurus dibandingkan dengan hasil pegukuran GPS Geo Tracker, padahal di lapangan kabel dibentangkan relatif lurus. Namun demikian, untuk pengukuran elevasi atau ketinggian, pengukuran menunjukkan bahwa data pengukuran oleh GPS Garmin lebih akurat dibanding dengan GPS GeoTracker. Oleh karena itu, data dari pengukuran keduanya digunakan dalam analisis hasil geolistrik. Untuk data plot posisi elektrode digunakan hasil pengukuran GPS Geo Tracker sedangkan untuk menggambarkan kemiringan lereng digunakan data GPS Garmin.

Hasil pengukuran geolistrik dianalisis dan diolah dengan Res2dinv 3.5.3 sehingga dihasilkan penampang 2D kondisi bawah permukaan di lapangan. Interpretasi struktur batuan bawah permukaan kemudian dilakukan berdasarkan nilai tahanan jenis atau resistivitasnya. Interpretasi dilakukan berdasarkan rentang nilai resistivitas dan digabungkan dengan pengamatan kondisi geologi di lapangan. Selain itu, untuk meningkatkan akurasi interpretasi litologi di Legok Emo, dilakukan juga perbandingan dan kajian literatur terhadap beberapa penelitian terdahulu, tentang pengukuran geolistrik, khususnya pada beberapa penelitian mengenai nilai tahanan jenis batuan di daerah longsor vulkanik.

Menurut Kirsch (2006, dalam Singhal and Gupta, 2010) material lempung memiliki nilai resistivitas $10-30 \Omega \mathrm{m}$; batuan kompak memiliki nilai resistivitas > $2000 \Omega \mathrm{m}$; kerikil, pasir jenuh air memiliki nilai resistivitas 60 $200 \Omega \mathrm{m}$; kerikil, pasir kering memiliki nilai resistivitas 500 - $2000 \Omega \mathrm{m}$; dan batuan terekahkan memiliki nilai resistivitas $60-2000$ $\Omega$ m. Sedangkan Akpan et al. (2015) membagi material lempung pasiran dengan nilai resistivitas $1-6 \Omega \mathrm{m}$ atau dapat diasumsikan material lempung atau lanau memiliki nilai resistivitas $\sim 10 \Omega \mathrm{m}$. Nilai resistivitas $\sim 20 \Omega \mathrm{m}$ masih diperkirakan berupa material lempung pasiran dan material klastik lainnya.

Selain itu, menurut Siregar et al. (2016), lempung tersaturasi memiliki rentang nilai resistivitas 11,8 - 18,6 $\Omega \mathrm{m}$ dan air 7,5 $\Omega \mathrm{m}$; batupasir jenuh diindikasikan dengan nilai resistivitas $216 \Omega \mathrm{m}$; dan posisi bidang gelincir dicirikan dengan nilai resistivitas $18,6 \Omega \mathrm{m}$ atau $7,5-46 \Omega \mathrm{m}$. Sedangkan menurut Ling et al. (2016), nilai tahanan jenis $<15 \Omega \mathrm{m}$ berasosiasi dengan lempung; nilai > $50 \Omega \mathrm{m}$ berasosiasi dengan tanah kerikil dan batupasir tidak lapuk; nilai resistivitas $50 \Omega \mathrm{m}$ diidentifikasi berupa batupasir; tanah kerikil berasosiasi dengan nilai resistivitas 20 - $40 \Omega \mathrm{m}$; dan bidang gelincir dengan nilai resistivitas $10 \Omega \mathrm{m}$; < $30 \Omega \mathrm{m}$; dan $<20 \Omega$ m karena adanya batupasir terlapukkan dan batulempung serta ketersediaan air tanah yang melimpah.

Nilai resistivitas di daerah Legok Emo kemudian ditentukan berdasarkan rentang nilai resistivitas yang telah didefinisikan oleh beberapa peneliti tersebut di atas serta pengamatan dan analisis geologi lokasi Legok Emo. Hal ini dikarenakan nilai resistivitas batuan berbeda-beda bergantung pada kondisi geologi daerah penelitian. Berdasarkan hal tersebut maka batuan yang terdapat di lokasi di daerah Legok Emo diinterpretasikan tersusun atas lapisan tanah permukaan, breksi terlapukkan, batupasir tufan, tuf, dan batuan beku Andesit agak terlapukkan atau terkekarkan. Lapisan permukaan memiliki rentang nilai tahanan jenis 50 - $150 \Omega \mathrm{m}$ dengan kedalaman 3 meter hingga sekitar 5 meter. Kecuali pada penampang geolistrik lintasan dua di bagian tenggara, lapisan permukaan memiliki rentang > $150 \Omega \mathrm{m}$ dikarenakan pada lokasi tersebut dipengaruhi oleh nilai resistivitas material lapukan komponen breksi. Lapisan tuf memiliki nilai resistivitas $9-30 \Omega \mathrm{m}$. Ketebalan lapisan ini diperkirakan $10-15$ m. Ketebalan lapisan ini dipengaruhi oleh posisi pengukuran geolistrik, sehingga ketebalan material tuf dapat berbeda bergantung lokasinya. Lapisan tuf yang bersifat kedap air ini dapat menjadi bidang gelincir dan menjadi penyebab munculnya mata air pada lereng Legok Emo. Lapisan breksi memiliki rentang nilai tahanan jenis $30-200 \Omega m$. Sedangkan batuan beku Andesit terlapukkan atau terkekarkan memiliki nilai tahanan jenis > $200 \Omega \mathrm{m}$. Hasil interpretasi dan penampang 


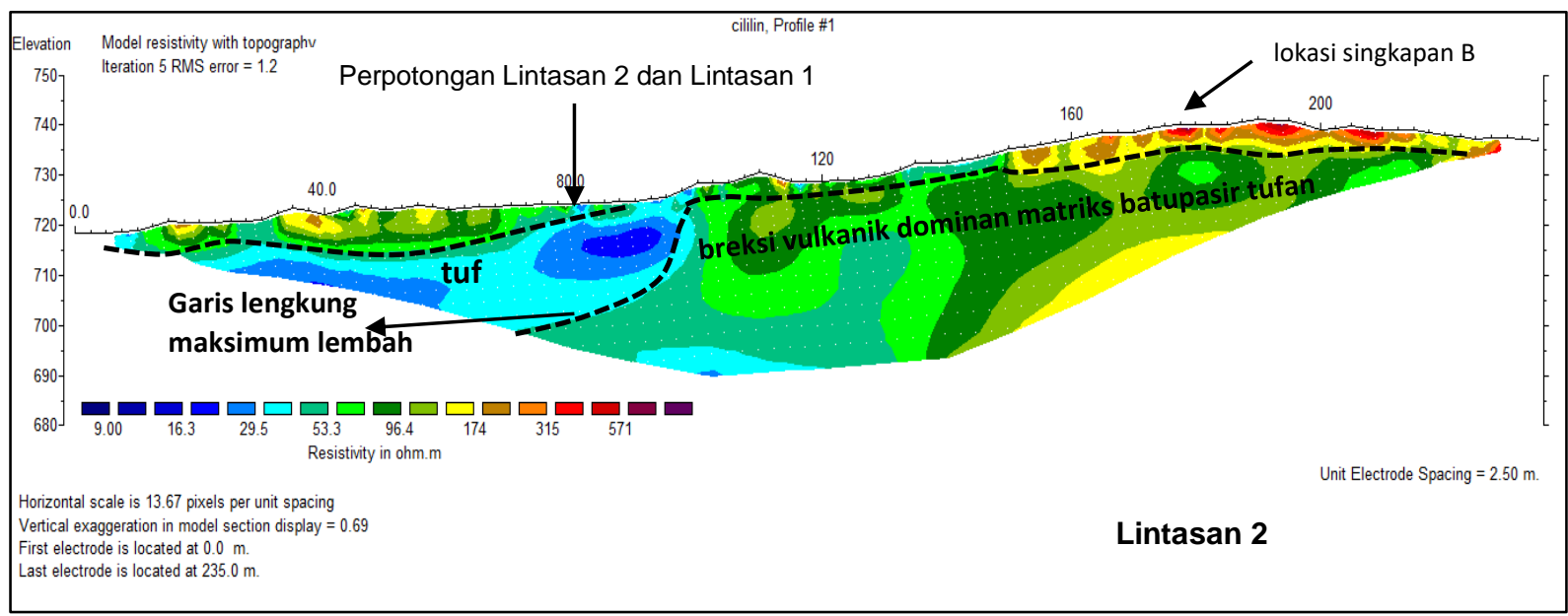

Gambar 9. Penampang geolistrik lintasan 1 menunjukkan perlapisan searah kemiringan lereng. Batuan tersusun oleh batuan beku Andesit agak terlapukkan atau terkekarkan di bagian dalam atas kemudian breksi vulkanik dan batupasir tufan, tuf dan di permukaan terdapat batuan breksi vulkanik terlapukkan.

Barat Daya

Timur Laut

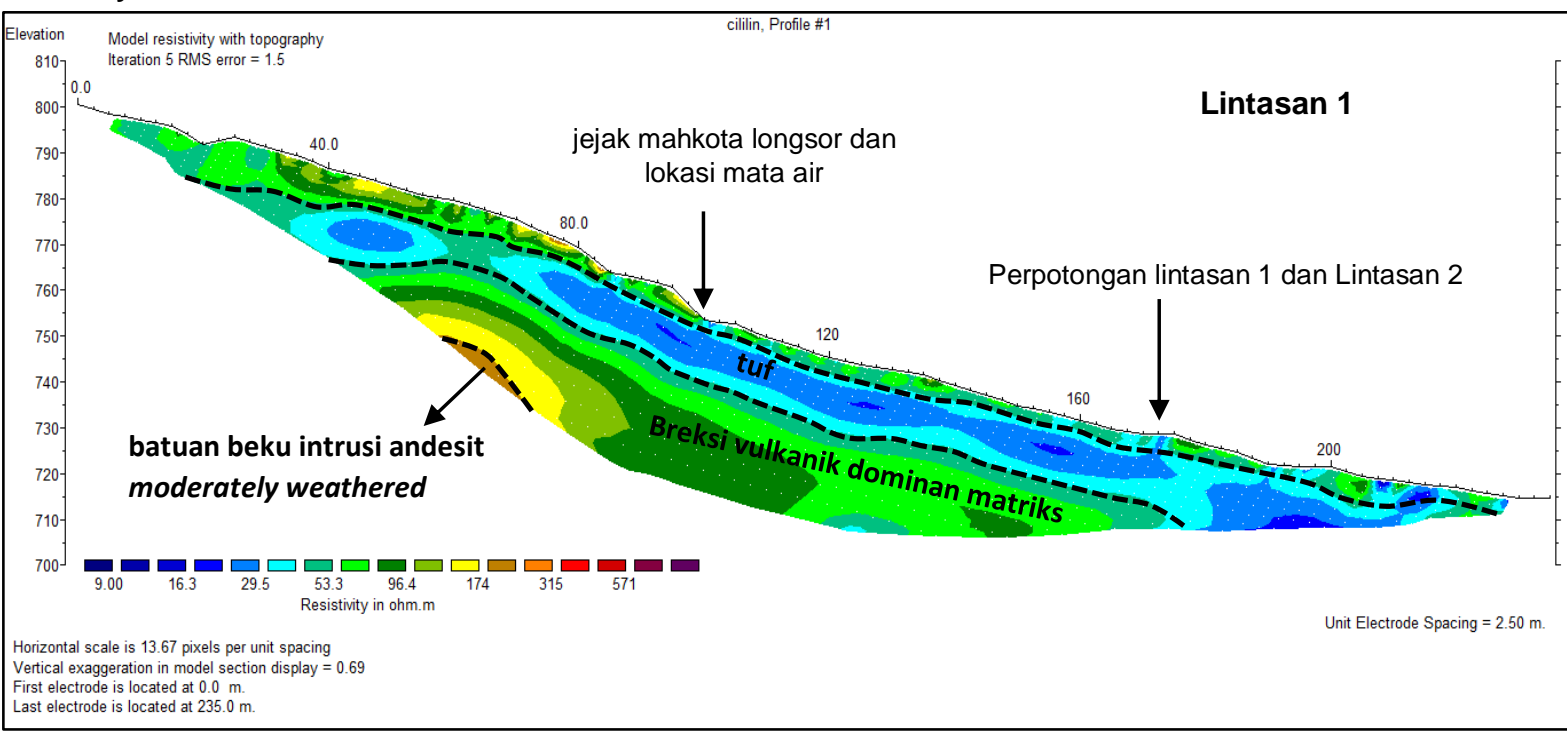

Gambar 10. Penampang geolistrik lintasan 2 menunjukkan batuan vulkanik tersusun oleh breksi vulkanik tanpa menunjukkan perlapisan.

\section{KESIMPULAN}

Gunung Geger Pulus di Kecamatan Cililin, Kabupaten Bandung Barat, Jawa Barat memiliki geomorfologi berbentuk kerucut yang merupakan ciri khas batuan intrusi. Batuan intrusi ini tersusun oleh Andesit yang mengandung augit, hiperstene dan hornblende dengan matriks yang mengaca. Di sekitar lereng bagian bawah, batuan Andesit ini ditutupi oleh batuan vulkanik yang lebih muda yang terdiri dari breksi tufan dan tuf. Segmen lereng Gunung Geger Pulus di Legok Emo mempunyai kemiringan lereng sekitar $35^{\circ}$ hingga $22^{\circ}$. Lereng ini tersusun oleh residual soil di bagian atas kemudian bergradasi ke bawahnya batuan yang dengan tingkat pelapukan completely weathered, highly weathered dan moderately weathered dengan tebal mencapai hingga sekitar 3 meter. Berdasarkan analisis laboratorium yang didapatkan dari pemboran tanah tidak 
terganggu atau undisturbed sample didapatkan bahwa jenis tanah pada Gunung Geger Pulus adalah $\mathrm{CH}$ atau clay high-plasticity. Hasil survei dan analisis geolistrik serta adanya jejak longsor dan mata air menunjukkan bahwa lokasi ini rawan longsor dangkal hingga ketebalan 3 meter dan maksimum sekitar 5 meter dimana batuan breksi terlapukkan terdapat di atas batuan tuf yang relatif kedap air. Tuf berfungsi sebagai bidang gelincir dan longsor dapat dipicu oleh curah hujan yang tinggi.

\section{PERSANTUNAN}

Kegiatan ini didanai oleh anggaran DIPA PTRRB BPPT Tahun 2019. Penulis mengucapkan terimakasih kepada Direktur PTRRB Ir. Eko Widi Santoso, M.Si. dan Kabag PTRRB Ir. Nur Hidayat M.T. yang telah memberikan kesempatan dan semua dukungan agar studi ini dapat terlaksana. Terima kasih juga diucapkan kepada Ir. Wiwiek Dwi Susanti, M.T. yang telah memberikan dukungan data analisis sampel tanah dari pemboran dangkal untuk studi ini.

\section{DAFTAR PUSTAKA}

Akmam, H. Amir, A. Putra, R. Anshari and N. Jalinus. 2019. Implementation of Leastsquare Constrain Inversion Method of Geoelectrical Resistivity Data WennerSchlumberger for Investigation the Characteristics of Landslide. The 2018 International Conference on Research and Learning of Physics. IOP Conference Series: Journal of Physics: Conference Series,1185 (2019) 012013: $1-10$.

Akpan, A. E., A. O. Ilori and N. U. Essien. 2015. Geophysical Investigation of Obot Ekpo Landslide Site, Cross River State, Nigeria. Journal of African Earth Sciences, 109: 154-167.

ASTM, 2008. Practice for Classification of Soils for Engineering Purposes (Unified Soil Classification System). American Society for Testing and Materials. ASTM D 2487.

Azman, M. I. M. F. 2018. Slope Failure Assessment In Penang Island Using Geoelectrical Methods. M.Sc. Thesis, Universiti Sains Malaysia. 116p.

Badan Geologi. 2017 a. Laporan Singkat Pemeriksaan Gerakan Tanah Di Desa Cililin, Kecamatan Cililin, Kabupaten Bandung Barat, Provinsi Jawa Barat, 29 Maret 2017. [terhubung berkala]. http://www.vsi.esdm.go.id/index.php/ gerakan-tanah/kejadian-gerakan-tanah/ 1504-laporan-singkat-pemeriksaangerakan-tanah-di-desa-cililin-kecamatancililin-kabupaten-bandung-barat-provinsijawa-barat [16 Maret 2020].

Badan Geologi. 2017 b. Laporan Singkat Pemeriksaan Gerakan Tanah Di Kecamatan Cililin, Kabupaten Bandung Barat Provinsi Jawa Barat. [terhubung berkala]. https://vsi.esdm.go.id/index. php/gerakan-tanah/kejadian-gerakantanah/1572-laporan-singkat-pemeriksaan -gerakan-tana-di-kecamatan-cililinkabupaten-bandung-barat-provinsi-jawabarat [23 Maret 2020].

Daryono, L. R., A. Hendratno, M. Nukman and E. Hartantyo. 2018. Landslide Identifications Based on Geology and Geoelectricity Mapping Analysis, Study Area: Road Province Pacitan-Ponorogo, East Java, Indonesia. Conference Proceedings EAGE-HAGI 1st Asia Pacific Meeting on Near Surface Geoscience and Engineering April 2018, 2018: 1-6.

Kirschbaum, D. B., T. Stanley, and J. Simmons. 2015. A Dynamic Landslide Hazard Assessment System for Central America and Hispaniola. Natural Hazards Earth System Science, 15: 2257-2272.

Lidauer, Simon, B. Jochum, D. Ottowitz, M. and T. Glade. 2018. Geoelectric Longtime Monitoring: Changes and Pattern within Subsurface Resistivity During Different Precipitation Events in the Salcher Landslide, Gresten (Lower Austria). 20th EGU General Assembly. EGU2018. Proceedings from the conference 4-13 April 2018 in Vienna, Austria: 12679.

Ling, C., Q. Xu, Q. Zhang, J. Ran. and H. Lv. 2016. Application of Electrical Resistivity Tomography for Investigating the Internal Structure of a Translational Landslide and Characterizing Its Groundwater Circulation (Kualiangzi landslide, Southwest China). Journal of Applied Geophysics, 131: 154-162.

Loke, M. H. 1999. Electrical Imaging Surveis For Environmental and Engineering Studies 2D and 3D Electrical Imaging Surveis. Penang, Malaysia.

Pratiwi, E. S., J. Sartohadi and Wahyudi. 2018. Geoelectrical Prediction for Sliding Plane Layers of Rotational Landslide at the Volcanic Transitional Landscapes in Indonesia. IOP Conference Series: Earth and Environmental Science, 286: 1-9. 
Segoni, S., V. Tofani, A. Rosi, F. Catani and N. Casagli. 2018. Combination of Rainfall Thresholds and Susceptibility Maps for Dynamic Landslide Hazard Assessment at Regional Scale, Frontiers in Earth Science, 6, Article 85: 1-11.

Singhal, B. B. S. and R. P. Gupta. 2010. Applied Hydrogeology of Fractured Rocks. Second Edition. Springer, pp 1314; 36-39; dan 76.

Siregar, R. N., I. N. Sinarta, Sismanto and E. Mohammad. 2016. Ground Penetrating Radar And 2-D Geoelectricity Application for Detecting Landslide in Abang District, Karangasem Regency, Bali. International Journal of Engineering Research and Application, 6(8): 51-55.

Sudjatmiko. 1972. Peta Geologi Lembar Canjur, Jawa. Pusat Penelitian dan Pengembangan Geologi.

Tejakusuma, I. G. 2017. Interaksi Faktor yang Mempengaruhi Longsor Jati Radio di Kecamatan Cililin, Kabupaten Bandung Barat, Jurnal Sains dan Teknologi Mitigasi Bencana, 12 (1) : 53-61.

Yatini, Y and I. Suyanto, I. 2018. Identification of Slip Surface Based on Geoelectrical Dipole-dipole in the Landslides Hazardous Area of Gedangsari District, Gunungkidul Regency, Province of Daerah Istimewa Yogyakarta, Indonesia. International Conference on Earth Science, Mineral, and Energy 11-12 October 2018, Yogyakarta, Indonesia. IOP Conference Series, Earth and Environmental Science, 212 (2018) 012013: 1-8.

Yusof, N. M., B. Pradhan, H. Z. M. Shafri, M. N. Jebur and Z. Yusoff. 2015. Spatial Landslide Hazard Assessment Along the Jelapang Corridor of the North-South Expressway in Malaysia Using High Resolution Airborne LiDAR Data. Arabian Journal of Geoscience, 8: 97899800. 